\title{
Innovation in Teaching and Learning Through Creative Art Model
}

\author{
Sri Milfayetty \\ The State University of Medan, North Sumatera, Indonesia
}

\begin{abstract}
The aim of this study was to develop an innovation in teaching and learning, called creative art model. The method used was research and development by adapting Borg and Gall model. This model was developed based on students' self, social competences, and cooperation among students. The procedures in this study were as follows: i) premilinary survey was conducted to produce software to be used in assesing students' needs; (ii) the creative art model chart was designed; and (iii) the model was implemented and evaluated. Data were collected by identifying and analyzing how the creative art model improved the quality of teaching and learning process. The results indicated that the creative art model could improved the quality of the teaching and learning by developing lesson plans. It also has been found that students' self and social competences were improved due to the improvement of cooperation among students.
\end{abstract}

Keywords: Innovation, Teaching, Learning, Creative, and Art

\section{Introduction}

The reposition of curicula of teacher education which has been declared by the Ministry of Education in Indonesia from based on competence to be based on competence qualification or KKNI. It has resulted in the need to replace the old model with the innovative one in teaching and learning. To be able to accomodate its new function, then the new model should have characteristics, such as the capabilities to manage teaching and learning activities, integratedly. Developing the new model means to develop four teacher's competencies such as self, social, pedagogy and professional competencies simultaneously. Preliminary studies found that teaching and learning through creative art has been proved to be theoretically met the requirements. However, the model has not been tested necessarily to prove its practical efficiency. In general, the purpose of this study was to improve the quality of teaching and learning to develop of self and social competencies through creative art model. Specifically, the objectives of this study were: (i) to use a software by which students' self and social competence will be assesed and analysed (ii) Based on the data obtained in the software, to design a model teaching and learning through creative art.

\section{Literature Reviewe}

The development of student by Chickering's seven vectors developmental theory consits of competence development, stable in emotion, interdependency, mature in interpersonal relationship, identity, goal of life and integrity (Chickering and Reisser, 1993 in Milfa 2012). The process of these development happened in a life time. In the other side, students have to develop their competences to be a teacher such as self, social, pedagogy and professional. The preliminary research showed that teaching and learning in education program at university were focused on pedagogy and profesional comptences. It caused that the student competencse in self and social as a teacher did not develop properly. From this situation, teaching and learning in convensional model did not suitable anymore. Therefore, a new model of teaching and learning should be developed. The new developed model should be develop student. As told by Chickering in simultan theory, i.e., teacher's competences, especially in self and social competences. Self comptence such as: steady, stable, adult,wise, command, model, and noble character. Social competences: communicate effectively, empathetically, and court. From this competences, students would be able to build relation by adapted Rogers Triangle Theory that was unconditional positive regards, emphaty, and congruence (Rogers 1978). Due to these, students could develop interconnection with other (Cozolino 2014). The model of teaching and learning through creative art (TLCA ) were assumed relevan to these situation. The reason was creative art was consisted of creative visualization, story, drawing, drama, clay, puppet, movement, music, mask and game (Maichiodi,2007). Because of this activity would made mind, body and soul of 
the student stimulate. The experience in doing creative art could made the student knowing self and other, enjoy with other, positive, satisfaction, happiness and dignity.

The concept used to design the new model in this study was taken from the theory of cooperative learning and the theory of creative art. It was stated that the success of teaching and learning in developing self and social indicated by criteria such as: (i) activities planning are based on students self and social quality map, (ii) efficient organization of students and activities in the classroom, and (iii) motivating learning and countinuous control. The map of students need comprise aspects such as students': (i) self competence, and (ii) social competence.Generally, there are two aspects to be considered as related to creative art model in teaching and learning. They are: (i) level of service which comprises: learning readiness session such as creative visualization, drawing , music (ii) direction of learning which includes: talking, drama, game, clay, puppet and movement. The Model shown in Fig. 1.

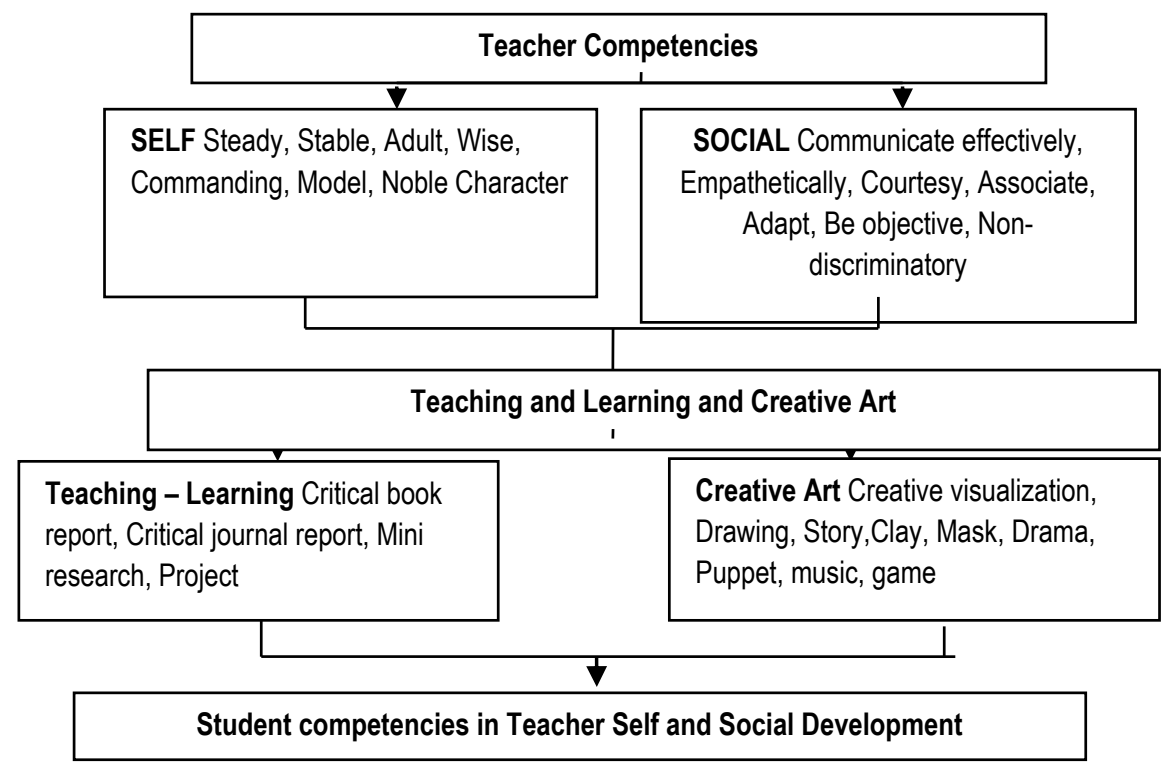

Figure 1. Teaching and Learning Through Creative Art (TLCA) Model

\section{Methodology:}

The method used in this study was research and development which was adopted from Borg, Walter (1983). The procedures were as follows: (i) preliminary survey, (ii) model development, (iii) model testing, (iv) model validation, and (v) model socialization. This method was done in three stages. A preliminary survey conducted was data collecting on students self and social competencies. Data collection was performed through the self and social assesment software. The data obtained were descriptively analysed to be further used in mapping students'self and social profile. The teaching and learning through creative art model (TLCA) based on students competence was resulted from the preliminary survey. The research question was: how does the TLCA model improve the quality of students' self and social competencies by teaching and learning?

Population in this study was students in The State University of Medan (Unimed), Indonesia in year 2016, those who take psychology of education subject. Samples were collected randomly, i.e., four classes from 44 classes in Faculty of Mathematic and Natural Sciences with amount 80 students. The data were collected through software of self and social assesment. Methods applied in this study were self report of the students and software self and social development. Collected data were analyzed using percentage method, in addition, student's self and social competencies were analyzed using software application. The procedure in this study is shown in Table 1 
Table 1. The Procedure of Study

\begin{tabular}{|c|c|c|}
\hline Activities & Method & Goal \\
\hline \multicolumn{3}{|l|}{ First Year: 12 month } \\
\hline \multicolumn{3}{|l|}{ 1. Preliminary Survey } \\
\hline $\begin{array}{l}\text { Student Self and social development } \\
\text { Indicator: } \\
\text { Student Self and Social Map } \\
\text { Analyzing need assesment }\end{array}$ & Use Software to collect data & $\begin{array}{l}\text { Base line data to design teaching } \\
\text { and learning and creative art }\end{array}$ \\
\hline \multicolumn{3}{|l|}{ 2.Model Design } \\
\hline $\begin{array}{l}\text { Teaching and learning need identification } \\
\text { Self and Social Development } \\
\text { Design the instruction } \\
\text { Try Out }\end{array}$ & $\begin{array}{l}\text { Analysis to: } \\
\text { Preliminary survey report } \\
\text { Expert judgement }\end{array}$ & $\begin{array}{l}\text { Teaching and Learning Through } \\
\text { creative art model } \\
\text { Try Out Model result } \\
\text { Model revised }\end{array}$ \\
\hline \multicolumn{3}{|l|}{ Second Year : 12 month } \\
\hline \multicolumn{3}{|l|}{ Try out Model at Lecture } \\
\hline Model validation & $\begin{array}{l}\text { Teaching and Learning Through } \\
\text { creative art model }\end{array}$ & $\begin{array}{l}\text { Teaching and Learning Through } \\
\text { creative art model } \\
\text { training for lecturer }\end{array}$ \\
\hline Socialyzing the model & Workshop & Activities report \\
\hline Study report & Study analysis & $\begin{array}{l}\text { Work Book for Teaching and } \\
\text { Learning Through creative art } \\
\text { model }\end{array}$ \\
\hline
\end{tabular}

\section{Results and Discussion:}

From this study, it has been found that the result of software application could be used as a foundation to TLCA model design. The model was used in mechanism of TLCA instructed. The procedures of TLCA model were found to be comprehensive than the conventional model, in terms of teaching and learning acomodate self and social stimulation through creative art. The process of TLAC more integrative and holistik. The student told that creative visualization and music were excelence done in TLCA. They could imagine something by creative visualization. Feel relax after using it with instrumental music. They could drawing everything they saw in creative visualization easily. They could talk about their drawing while the others hear it. Using clay the student built his self. The results of the study is shown in Figure 2.

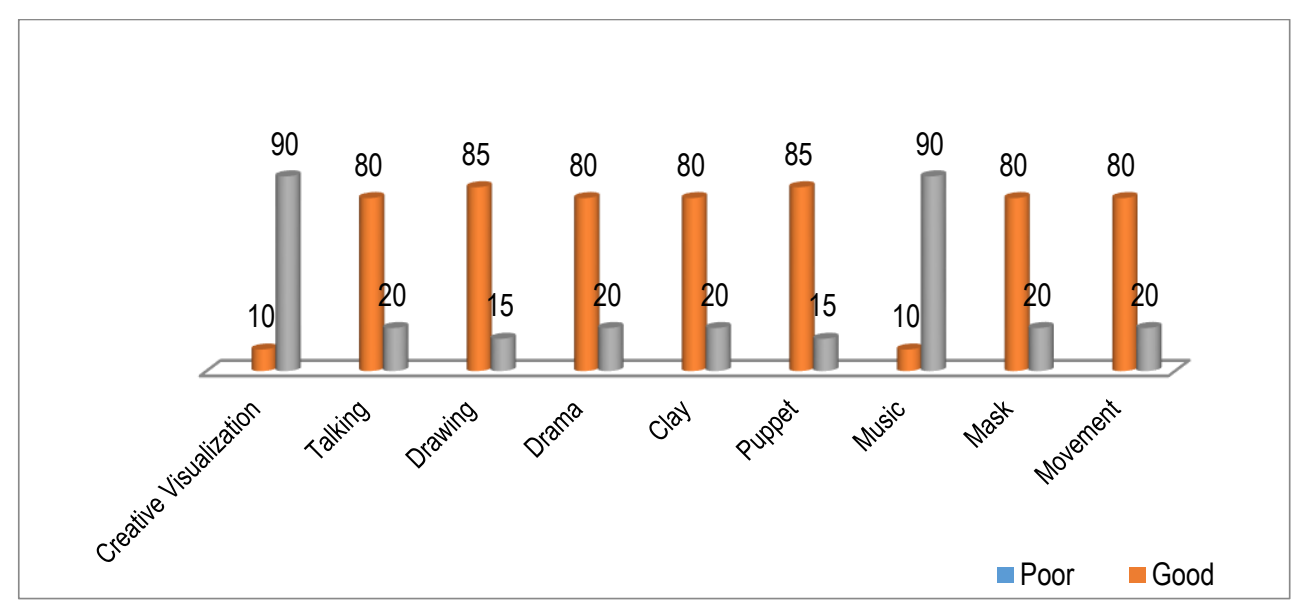




\section{Figure 2. Creative Art in Teaching and Learning activities}

Theory of contact by Lynne, (2010) consisted of physical, emotional and metaphorical. Acitivity with clay as physical contact, sensation experiment influenced feeling and emotional contact connected simultaniously with imagination and metaphor. This situation made knowing contact between student and others. Understood about himself by methafor is shown in Figure 3. Others could empathy to the student. Because of this situation made in every time in teaching and learning process, interconnection between student happened. One attached by the other (Bowlby J, 1998).

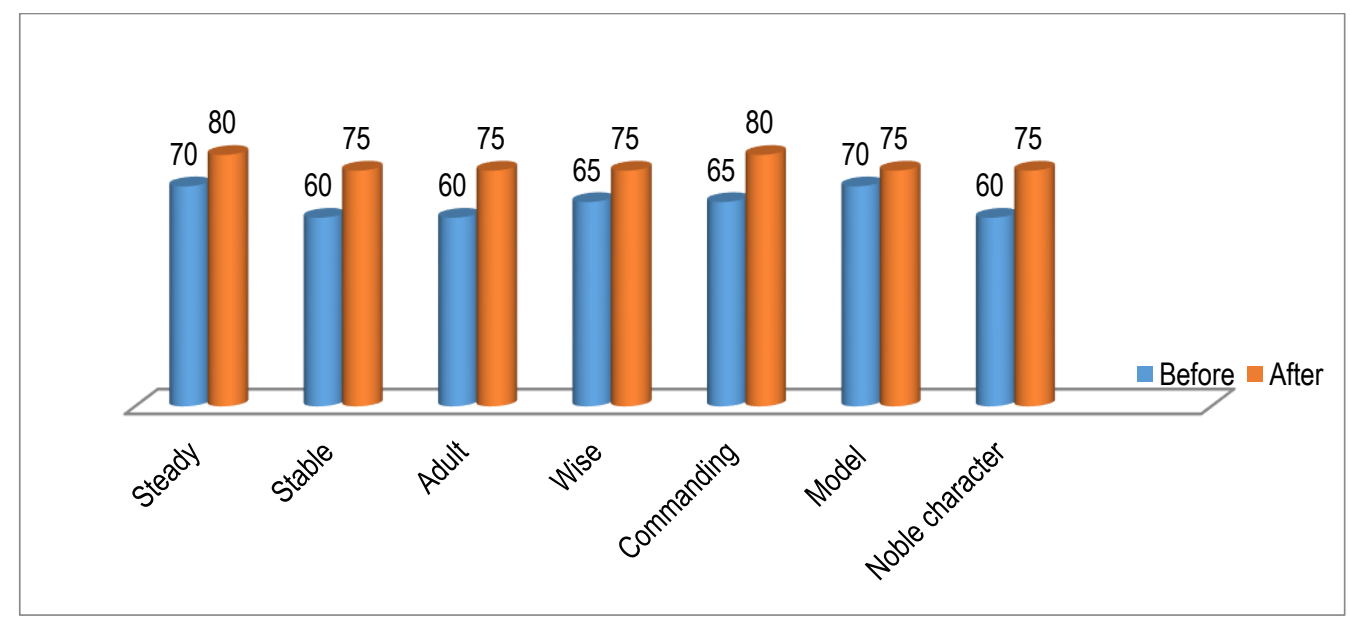

\section{Figure 3. Self-Competences}

The results of evaluation about students's activities, such as talking, drama, clay, puppet, mask and movement were found to be good. The metaphor of clay was affected to mind of student, body and soul stimulated (Sapolsky 2012). They understood more about themselves and let other knew about the metaphore of clay. Puppet resulted interconnection between each other (Mills,Joice, Crawley, Richard. J.(2011). Process mirroring, and matching energy (Cozolino,2014) happened in this situation and the students'social competences as communicate effectively,empathetically, courtesy as in Figure 4. Seemed that creative activity in the class room that done integrated with teaching activity stimulate self and social competence developement. Students became communicate effectively, empathetically, associative and adaptable after the study. This was happened also in courtesy, objectivity and non discriminatory. The student could develop their windows of tolerance (Keer,2015). Prevent them in hypoarousal as fight, fly an freeze in problem solving. 


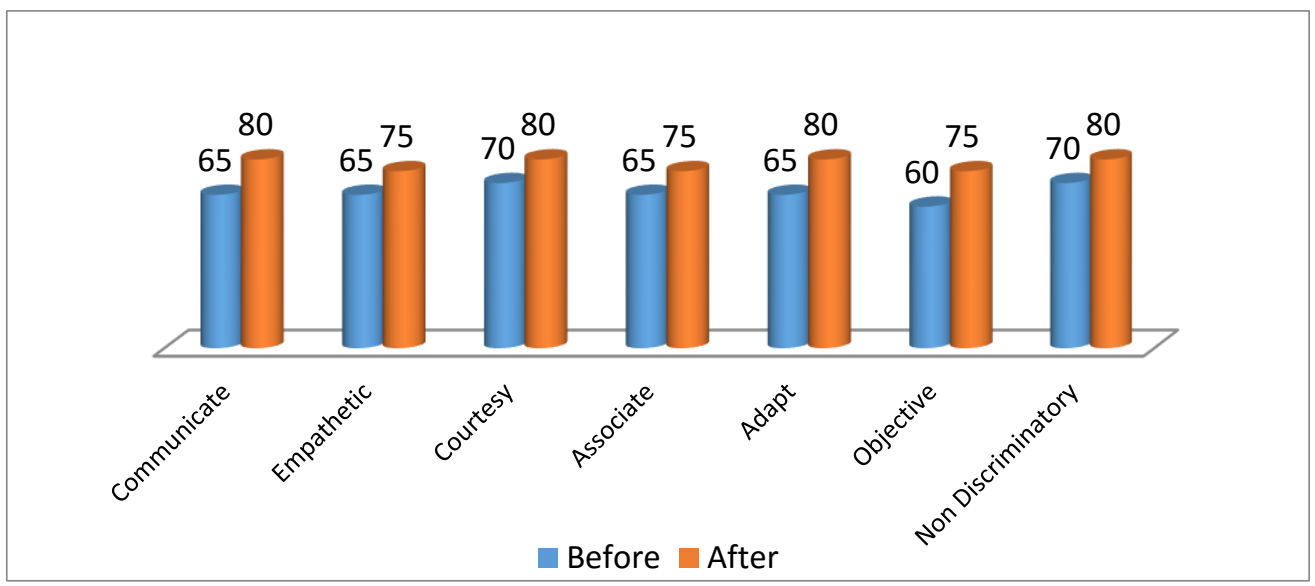

\section{Figure 4. Social Competences}

At last, the results showed that TLAC model could improved students' self and social competences. The data from software could be used to design lesson plans for teaching and learning. The students were commented that TLCA made joyfull learning. They told that self and social development better than before. In addition the lectuter commented that classroom did not talking about academic only . It seemed that the classrom talked about the student in holistic. The self, social, pedogogy and professional commpetences more easier to be achieved. Learning processes were not only in cognitive ways, but also in emotional, social, and practical ways

Furthermore, this model could give a chance to student in learning naturally and changed from articificial learning. Based on the results, it could be stated that could overcome the weakness of the traditional approach in teaching and learning, such as: (i) the services provided in the model were based on comprehensive assessment of students' need and competences, (ii) the activities were more controlable since any single decision was made based on data, (iii) the cooperative interactions between lecturer and students, (iv) the sense of responsibility as a professional teacher was grew among the students, and (v) the more pleasant and conducive atmosphere were established.

Besides that, the TLCA model provided some beneficial contribution to students, which was never achieved in the traditional model, in the way: (i) increasing students' understanding of self and social teachers'competence activities, (ii) promoting interaction among peers and lecturers, and (iii) developing self confidence to be successful in careers, and (iv) helping students in solving their problems efficiently and effectively.

\section{Conclusions:}

The TLCA model could became an alternative response towards the government decisions in KKNI Curicula in teacher education from merely a conventional approach to holistic and integral of teaching and learning processes. The new model at the same time was found to be strengthened the role of lecturer in Indonesian. Teaching and learning in teacher education conventional way focus on pedagogy and professional competence. However, through creative art model, students could got their self and social competences, beside pedagogy and profesional competences.

\section{Acknowledgment}

Acknowledgments to the Ministry of Research, Technology and Higher Education of the Republic of Indonesia which has provided support for this paper to be presented orally at ICSS XII in Amsterdam 19-20 Mei 2017.

\section{References}

[1] Borg, Walter R. 1983. Educational Research.New York: Longman,Inc

[2] Bowlby J. ( 1998). Attachement and Loss. London : Pinguin Books Limited

[3] Cozolino,Louis J. (2014). The Neuroscience of Human Relationship : attachment and the Developing Social Brain. London : WW. 
[4] Norton \& Company.

[5] K.Keer.Laura. (2015). Live Within Your Window of Tolerance.San Fransisco:

[6] Lynne Souter Anderson. (2010). Touching Clay, Touching What. Paola Malta : Melita Press

[7] Mark Barnes.(2013). The Healing Path of Children. London : Play Therapy Press.

[8] Maichiodi,Cathy.A.(2007). The Art Therapy Sourcebook. New York: Mc.Graw Hill.

[9] Mills,Joice, Crawley, Richard. J.(2011). Theraupetic Metaphore for Children and the Child Within. New York : Roudledge

[10] Milfayetty, 2004. Student Support Services in Engeneering Faculty in State University Medan

[11] Ogden, Pat, Minton. Pain Clare.(2006). Trauma and The Body : A Sensory Motor Aproach to

[12] Psychoteraphy. New York: WW.Norton and Co.

[13] Rogers.C.R.(1978) . Personal Power. New York :Houghion Miffin Company 